\title{
A novel bFGF antagonist peptide inhibits breast cancer cell growth
}

\author{
QUCHOU LI $^{1}$, SUSU GAO ${ }^{1}$, YONGLIN YU ${ }^{1}$, WENHUI WANG ${ }^{1}$, XILEI CHEN ${ }^{1}$, RUIXUE WANG ${ }^{1}$, \\ TAO LI ${ }^{1}$, CONG WANG ${ }^{1}$, XIAOKUN LI ${ }^{1,2}$ and XIAOPING WU ${ }^{1,2}$ \\ ${ }^{1}$ Institute of Tissue Transplantation and Immunology, Jinan University, Guangzhou, Guangdong 510632; \\ ${ }^{2}$ School of Pharmaceutical Sciences, Wenzhou Medical College, Wenzhou, Zhejiang 325035, P.R. China
}

Received January 9, 2012; Accepted March 30, 2012

DOI: $10.3892 / \mathrm{mmr} .2012 .882$

\begin{abstract}
Breast cancer is the most common type of cancer in women worldwide. Elevated expression of the basic fibroblast growth factor (bFGF) has been found in patients suffering from breast cancer. We previously obtained a high-affinity bFGFbinding peptide (named P7) from a phage-display random heptapeptide library. In this study, we show that P7 peptides significantly inhibits the proliferation of the bFGF-stimulated MDA-MB-231 breast cancer cell line. Additional experiments revealed that the mechanisms of the $\mathrm{P} 7$ peptide inhibition of the cell proliferation of breast cancer cells stimulated with bFGF in vitro involved cell cycle arrest at the $\mathrm{G}_{0} / \mathrm{G}_{1}$ phase, blockade of the activation of Erk and P38 cascades and the upregulation of the expression of the growth inhibitor, proliferation-associated protein $2 \mathrm{G} 4$. These results suggest that the bFGF-binding peptide may have therapeutic potential in breast cancer therapy.
\end{abstract}

\section{Introduction}

The basic fibroblast growth factor (bFGF), belonging to the family of fibroblast growth factors (FGFs), is a pleiotropic factor involved in the processes of proliferation and differentiation of a wide variety of cells derived from the mesoderm and neuroectoderm. Its spatial and temporal expression are tightly regulated under physiological conditions. Abnormally elevated levels of bFGF are commonly observed in pathological conditions, such as arthritis and cancer. It has been reported that bFGF contributes to tumor growth via stimulating the proliferation of tumor cells $(1,2)$. Therefore, bFGF is regarded as a potential target for tumor therapy.

Breast cancer originates from the inner lining of milkducts or the lobules of breast tissue, and is over 100-fold more common in women than in men. Breast cancer comprises $22.9 \%$ of all cancers (excluding non-melanoma skin cancers) in women,

Correspondence to: Dr Xiaoping Wu, Institute of Tissue Transplantation and Immunology, Jinan University, Guangzhou, Guangdong 510632, P.R. China

E-mail:xp_wu2@yahoo.com.cn

Key words: basic fibroblast growth factor antagonist peptide, cell proliferation, cell cycle, mitogen-activated protein kinase pathway, proliferation-associated protein $2 \mathrm{G} 4$ and caused $13.7 \%$ of cancer deaths in women in 2008. The elevated expression of bFGF has been found in urine (3) and in the nipple fluid (4) of patients suffering from breast cancer. We previously isolated a high-affinity bFGF-binding peptide (named P7) from a random peptide library using phage display technology (5). The isolated peptide significantly suppresses bFGF-induced cell proliferation and angiogenesis (5). In this study, we further investigated the mechanisms behind the antiproliferative effect of the isolated peptide on breast cancer cells and evaluated its possible therapeutic potential in breast cancer.

\section{Materials and methods}

MDA-MB-231 cells were kept in our laboratory. DMEM and fetal bovine serum (FBS) were purchased from the Gibco Company. P7 peptides (PLLQATLGGGS) were synthesized by SBS Genetech (Beijing, China). Recombinant human bFGF was obtained from PeproTech (Rocky Hill, NJ, USA). Anti-Erk1/2 rabbit monoclonal antibody (mAb), anti-phosphorylated (phospho)-Erk1/2 rabbit $\mathrm{mAb}$, anti-P38 rabbit $\mathrm{mAb}$, anti-phospho-P38 rabbit $\mathrm{mAb}$, anti-GAPDH $\mathrm{mAb}$ and goat anti-rabbit $\operatorname{IgG}$ conjugated with horseradish peroxidase (HRP) antibody were purchased from Cell Signaling Technology (Danvers, MA, USA). Anti-proliferation-associated protein 2G4 (PA2G4) mAb was from Santa Cruz Biotechnology (Santa Cruz, CA, USA).

Cell viability assay. MDA-MB-231 cells were seeded in 96-well plates with $5 \times 10^{2}$ cells/well. After being cultivated for $24 \mathrm{~h}$, the cells were washed with PBS and serum-starved in serum-free DMEM with $0.02 \%$ FBS for $24 \mathrm{~h}$. The cells were then treated with serially diluted peptides, bFGF $(2.5 \mathrm{ng} / \mathrm{ml})$ alone, or bFGF $(2.5 \mathrm{ng} / \mathrm{ml})$ plus serially diluted peptides for $48 \mathrm{~h}$. The viability of the cells was determined by the methylthiazole tetrazolium (MTT) colorimetric assay as described previously (5).

Flow cytometric analysis of the cell cycle. Flow cytometry analysis was carried out to analyze the effect of $\mathrm{P} 7$ on the cell cycle progress of bFGF-stimulated cells. MDA-MB-231 cells were seeded in 12 -well plates with $1 \times 10^{5}$ cells/well. After being cultivated for $24 \mathrm{~h}$, cells were washed with PBS and serumstarved in serum-free DMEM with $0.4 \%$ FBS for $24 \mathrm{~h}$. The cells were then treated with serially diluted peptides, bFGF $(10 \mathrm{ng} / \mathrm{ml})$ alone, or bFGF $(10 \mathrm{ng} / \mathrm{ml})$ plus serially diluted 
peptides for $24 \mathrm{~h}$. Cells were collected and fixed in $70 \%$ icecold ethanol for $30 \mathrm{~min}$ at $4^{\circ} \mathrm{C}$. After being washed with PBS three times, the cells were stained by adding $300 \mu \mathrm{l}$ propidium iodide (PI) at the concentration of $50 \mu \mathrm{g} / \mathrm{ml}$. Percentages of cells at various phases of the cell cycle were analyzed using the ModFit DNA analysis program.

Mitogen-activated protein kinase (MAPK) activation assay. MDA-MB-231 cells were seeded in 12-well plates with $1 \times 10^{5}$ cells/well. After being cultivated for $24 \mathrm{~h}$, the cells were washed with PBS and serum-starved in serum-free DMEM with $0.4 \%$ FBS for $24 \mathrm{~h}$. The starved cells were treated with serially diluted peptides for $30 \mathrm{~min}$ prior to stimulation with bFGF $(10 \mathrm{ng} / \mathrm{ml})$ for $3 \mathrm{~h}$. After being washed with cold PBS, cells were lysed in $1 \mathrm{X}$ SDS-PAGE loading buffer. The lysate was clarified by centrifugation at $12,000 \mathrm{x}$ for $10 \mathrm{~min}$ at $4^{\circ} \mathrm{C}$ to remove the insoluble components. The samples were separated by $10 \%$ SDS-PAGE and transferred to a PVDF membrane $(350 \mathrm{~mA}$, $70 \mathrm{~min}$ ). The membrane was blocked with $5 \%$ non-fat dry milk in TBS buffer containing Tween-20 for $1 \mathrm{~h}$, and incubated with an anti-phospho-Erk1/2 mAb (1:1,000 dilution) and an antiphospho-P38 mAb (1:1,000 dilution) overnight at $4^{\circ} \mathrm{C}$, followed by a goat anti-rabbit IgG, HRP-linked antibody $(1: 1,000$ dilution) for $1 \mathrm{~h}$. Non-phospho-Erk1/2 and non-phospho-P38 were respectively used as the reference control. The blots were visualized with an ECL detection kit.

Western blot analysis of PA2G4 expression. MDA-MB-231 cells were seeded in 6 -well plates at $2 \times 10^{5}$ cells/well. After being starved for $24 \mathrm{~h}$, cells were treated with bFGF $(10 \mathrm{ng} / \mathrm{ml})$ or bFGF $(10 \mathrm{ng} / \mathrm{ml})$ plus $4 \mu \mathrm{M}$ peptides for $48 \mathrm{~h}$. Cells were collected and lysed to prepare the samples for electrophoresis on a $10 \%$ SDS-PAGE gel followed by transferring to a PVDF membrane. The membrane was incubated with an anti-PA2G4 $\mathrm{mAb}(1: 1,000$ dilution) and an anti-GAPDH mAb (1:1,000 dilution) overnight at $4^{\circ} \mathrm{C}$, followed by a goat anti-rabbit $\mathrm{IgG}$, HRP-linked antibody (1:1,000 dilution) for $1 \mathrm{~h}$. The blots were visualized with an ECL detection kit.

Statistical analysis. The data analysis was carried out with Quantity One 4.6 software. The statistical differences between the groups were determined using GraphPad Prism 5 software. The results are expressed as the means \pm standard deviation (SD). A p-value of $<0.05$ denoted a statistically significant difference.

\section{Results}

$P 7$ inhibits bFGF-stimulated proliferation of $M D A-M B-231$ cells. The effect of $\mathrm{P} 7$ peptides on the proliferation of bFGFstimulated MDA-MB-231 cells was determined using an MTT assay. The starved cells were treated with bFGF alone, bFGF plus various concentrations of $\mathrm{P} 7$, or $\mathrm{P} 7$ peptides alone for $48 \mathrm{~h}$. As shown in Fig. 1, P7 peptides significantly inhibited the proliferation of MDA-MB-231 cells induced with $2.5 \mathrm{ng} / \mathrm{ml}$ of bFGF, whereas the administration with P7 alone hardly suppressed the growth of MDA-MB-231 cells.

Inhibition of cell cycle progression. To determine the effect of $\mathrm{P7}$ peptides on the cell cycle distribution of MDA-MB-231

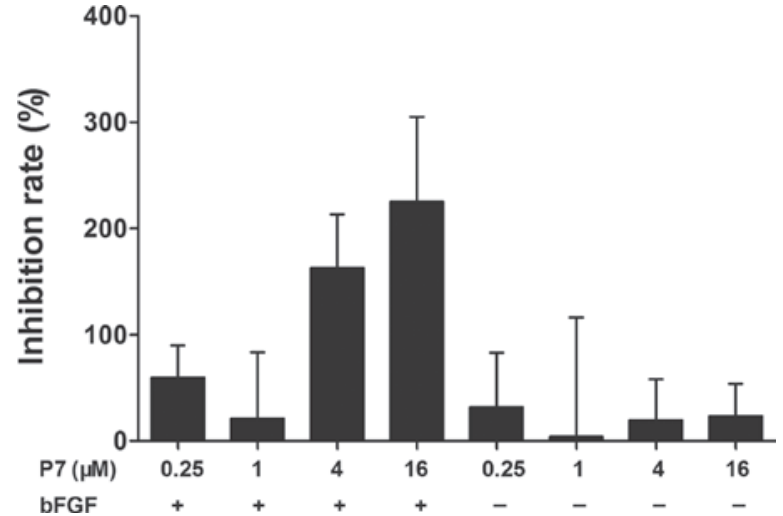

Figure 1. Inhibition of the basic fibroblast growth factor (bFGF)-stimulated proliferation of MDA-MB-231 cells by the synthetic P7 peptides. Starved cells were treated with $\mathrm{P} 7$ at the indicated concentrations, $2.5 \mathrm{ng} / \mathrm{ml} \mathrm{bFGF}$ alone or $2.5 \mathrm{ng} / \mathrm{ml} \mathrm{bFGF}$ plus $\mathrm{P} 7$ at the indicated concentrations, and cell proliferation was determined $48 \mathrm{~h}$ later. Data are presented as the means \pm $\mathrm{SD}$ of three independent experiments.

cells induced with or without bFGF, the starved cells were treated with $\mathrm{P} 7$ alone or bFGF plus various concentrations of P7 for $24 \mathrm{~h}$, and subjected to flow cytometry after PI staining. The results in Fig. 2 showed that exogenous bFGF increased the $\mathrm{S}$ phase cell ratio from $23.73 \pm 0.09$ to $30.82 \pm 0.05 \%$, and decreased the $\mathrm{G}_{0} / \mathrm{G}_{1}$ phase cell ratio from $65.70 \pm 0.69$ to $59.27 \pm 0.02 \%$. Compared to the bFGF group, synthetic P7 peptides significantly decreased the percentage of cells in the $S$ phase at the expense of cells in the $G_{0} / G_{1}$ phase. However, the administration of $\mathrm{P} 7$ alone did not alter the cell cycle distribution. These results suggest that $\mathrm{P} 7$ peptides specifically inhibit bFGF-stimulated cell proliferation by arresting the cells at the $\mathrm{G}_{0} / \mathrm{G}_{1}$ phase.

$P 7$ inhibits bFGF-induced MAPK activation. To determine whether P7 inhibits bFGF-stimulated cell proliferation via influencing the bFGF-triggered MAPK signaling pathway which is closely related to cell proliferation, the capacity of P7 peptides to suppress the activation of Erk1/2 and P38 stimulated with bFGF was assessed by western blot analysis. As shown in Fig. 3, exogenous bFGF significantly stimulated the phosphorylation of Erk1/2 and P38 signal molecules. Pre-treatment of the cells with various concentrations of P7 $(0.25-16 \mu \mathrm{M})$ for $30 \mathrm{~min}$ before stimulation with bFGF resulted in significant blockage of the activation of both signal molecules in a dose-dependent manner. P7 at the concentration of $16 \mu \mathrm{M}$ suppressed the activation levels of both detected signal molecules compared to the control. The administration of P7 alone showed little influence on the phosphorylation of Erk1/2 and P38 $(\mathrm{p}<0.05)$.

$P 7$ counteracts the regulatory effect of bFGF on PA2G4 expression. The combination of two-dimensional gel electrophoresis and matrix-assisted laser desorption/ionization time-of-flight (MALDI-TOF)/TOF mass spectrometry was applied to identify the P7-targeting-bFGF specific protein, PA2G4, which is closely related to the regulation of cell proliferation in colon cancer cells. In order to determine whether the regulatory effect of P7 on PA2G4 expression also occurs in breast cancer cells, western blot analysis was carried out to detect the expres- 


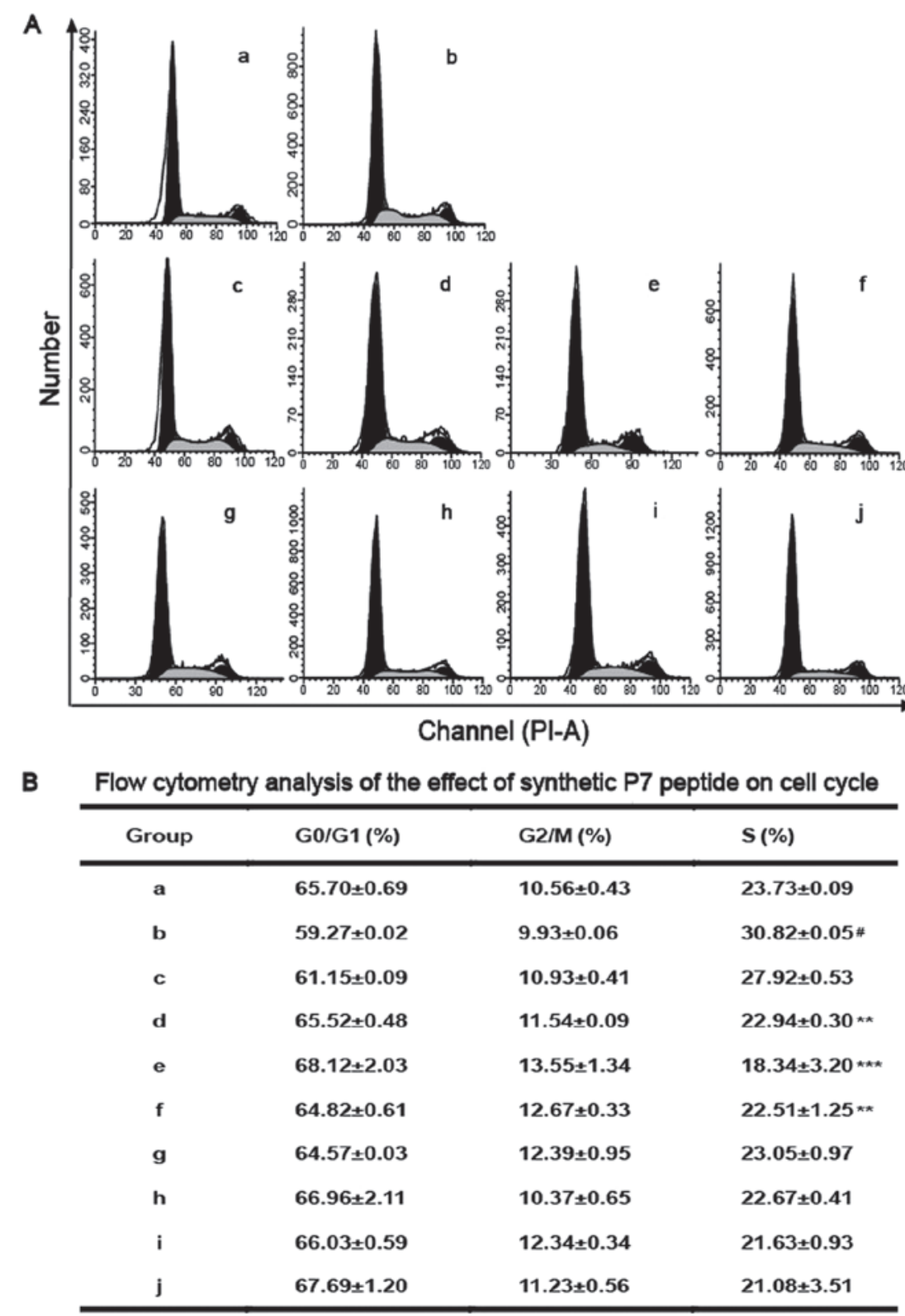

Figure 2. Effects of synthetic P7 peptides on cell cycle distribution of basic fibroblast growth factor (bFGF)-stimulated cells analyzed by flow cytometry. (A) Cells were starved for $24 \mathrm{~h}$ and then treated with (b) $10 \mathrm{ng} / \mathrm{ml} \mathrm{bFGF,} \mathrm{(c)} 10 \mathrm{ng} / \mathrm{ml} \mathrm{bFGF} \mathrm{plus} 0.25 \mu \mathrm{M} \mathrm{P} 7$, (d) $10 \mathrm{ng} / \mathrm{ml} \mathrm{bFGF}$ plus $1 \mu \mathrm{M} \mathrm{P7}$, (e) $10 \mathrm{ng} / \mathrm{ml}$ bFGF plus $4 \mu \mathrm{M} \mathrm{P} 7$, (f) $10 \mathrm{ng} / \mathrm{ml}$ bFGF plus $16 \mu \mathrm{M} \mathrm{P7}$, (g) $0.25 \mu \mathrm{M} \mathrm{P7}$, (h) $1 \mu \mathrm{M} \mathrm{P} 7$, (i) $4 \mu \mathrm{M}$ P7 and (j) $16 \mu \mathrm{M} \mathrm{P7} \mathrm{for} 24 \mathrm{~h}$; (a) control cells without treatment of bFGF or P7. Data shown are the representative images of three independent experiments. (B) Cell cycle distribution of the control and treated cells. Data are presented as the means $\pm \mathrm{SD}$ of three independent experiments. (a) ${ }^{*} \mathrm{p}<0.05$ vs. the control group; (b) ${ }^{* *} \mathrm{p}<0.01,{ }^{* * * *} \mathrm{p}<0.001$ vs. the bFGF group.

sion levels of PA2G4. The results showed that, consistent with the observation in colon cancer cells, PA2G4 expression was downregulated by bFGF stimulation and enhanced by $\mathrm{P} 7$ treatment (Fig. 4), suggesting that PA2G4 plays an important role in P7 couteracting the bFGF-stimulated proliferation in both colon and breast cancer cells.

\section{Discussion}

We previously isolated the bFGF-binding peptide, P7, with high homology to the immunoglobulin-like (Ig-like) domain III (D3) of bFGF receptors and demonstrated that P7 peptides exert strong inhibitory effects on the proliferation of bFGFinduced cells, including HT-29 and Balb/c 3T3 cells $(6,7)$.
Since diverse expression patterns of bFGF receptors are common in different types of cells, and the responses of cells to bFGF stimulation largely depend on the expression patterns of bFGF receptors on cell membranes, the role of bFGF in breast carcinoma is somewhat contradictory. Therefore, in this study, we attempted to determine the effect of P7 on bFGFstimulated breast cancer cells and to evaluate the potential of P7 in breast cancer therapy.

The results of the MTT assay demonstrated that the P7 peptides markedly suppressed the bFGF-stimulated growth of MDA-MB-231 cells, while little influence on cell growth was observed when cells were treated with P7 alone. bFGF exerts its mitogenic activity by regulating cell cycle distribution and MAPK signal transduction; therefore we further investigated 
A

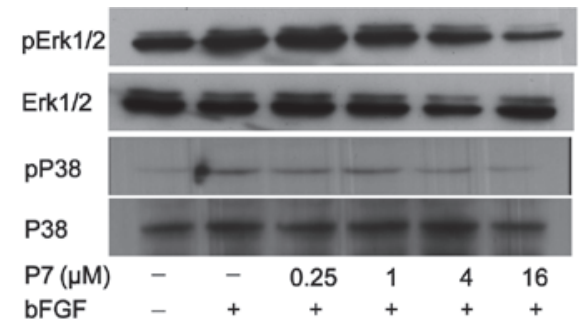

B
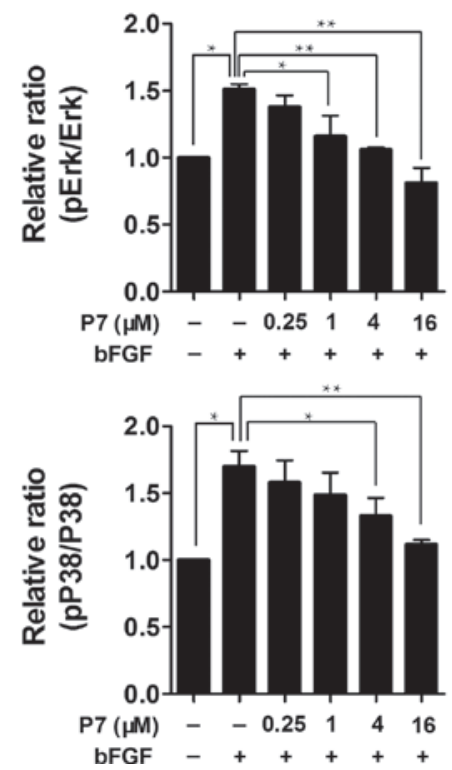
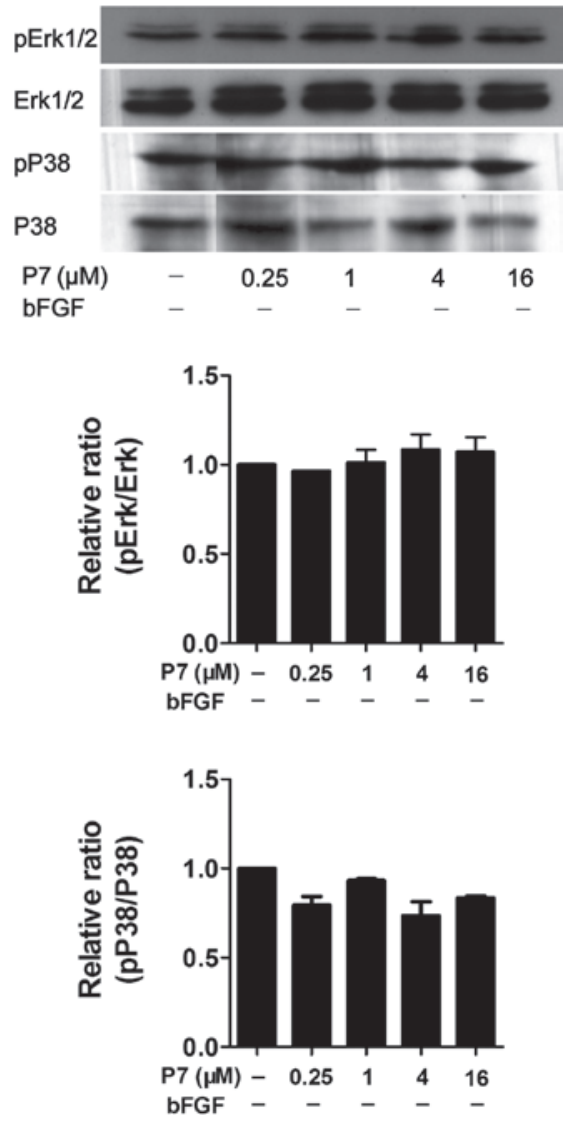

Figure 3. The synthetic P7 peptides suppressed the activation of Erk1/2 and P38 induced by basic fibroblast growth factor (bFGF). (A) The starved cells were pre-treated with P7 at the indicated concentrations for $30 \mathrm{~min}$ and then stimulated with $10 \mathrm{ng} / \mathrm{ml} \mathrm{bFGF}$ for $3 \mathrm{~h}$ (left panel), or treated with P7 alone at the indicated concentrations (right panel). The activation levels of Erk1/2 and P38 were detected by western blot analysis. (B) Density ratios of phosphorylated Erk1/2 (pErk1/2) to Erk1/2 (upper panel), and phosphorylated P38 (pP38) to P38 (bottom panel). ${ }^{*} \mathrm{p}<0.05,{ }^{* *} \mathrm{p}<0.01$.

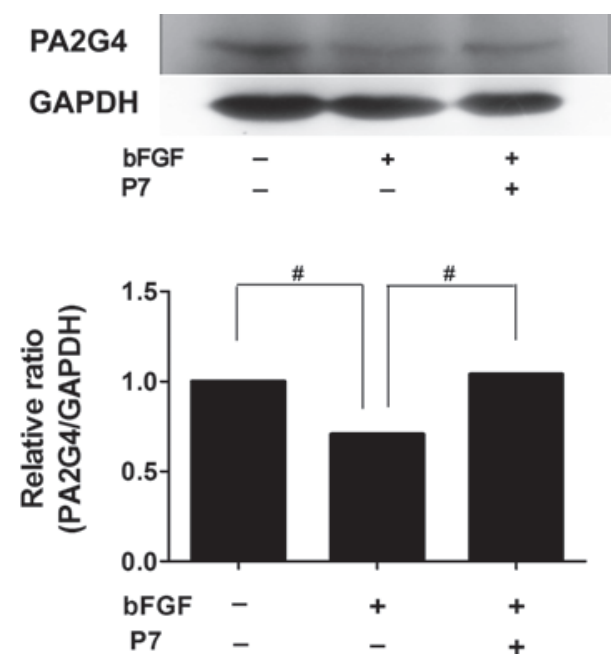

Figure 4. The synthetic P7 peptides counteracted the regulatory effect of basic fibroblast growth factor (bFGF) on proliferation-associated protein $2 \mathrm{G} 4$ (PA2G4) expression. The starved cells were treated with $10 \mathrm{ng} / \mathrm{ml} \mathrm{bFGF}$ alone, or $10 \mathrm{ng} / \mathrm{ml} \mathrm{bFGF}$ plus $4 \mu \mathrm{M} \mathrm{P} 7$ for $48 \mathrm{~h}$. The expression of PA2G4 was detected by western blot analysis. Sample loading was controlled by GAPDH protein quantification. ${ }^{\#} \mathrm{p}<0.05$.

how the P7 peptides influence the mitogenic activity of bFGF by analyzing the cell cycle progression and using MAPK activation assay.
bFGF promotes cell cycle progression via regulating the expression of cell cycle proteins involved in cell cycle entry and progression through the $G_{1}$ and $S$ phases (8). Cell cycle analysis showed that $\mathrm{P} 7$ arrested bFGF-stimulated cells at the $\mathrm{G}_{0} / \mathrm{G}_{1}$ phase, suggesting that $\mathrm{P} 7$ influences the expression of bFGF-regulated cell cycle proteins involved in the stimulation of cells from the $G_{0} / G_{1}$ to the $S$ phase, and then counteracts the mitogenic activity of bFGF in MDA-MB-231 cells.

Extracellular bFGF binds to its receptors, and activates the MAPK signaling pathway, which is a predominant signaling pathway mediating cell proliferation and consists of three cascades, Erk, P38 and JNK. The phosphorylation levels of Erk, P38 and JNK were detected to determine which cascade participates in the P7 inhibition of bFGF-induced proliferation. The results revealed that $\mathrm{P} 7$ suppressed bFGF-induced Erk1/2 and P38 phosphorylation in a dose-dependent manner. The administration of bFGF did not stimulate the activation of the JNK cascade (data not shown). P7 alone had little effect on the phosphorylation levels of the above three signal molecules. These results suggest that the Erk and P38 cascades, rather than the JNK cascade, are involved in mediating the inhibitory effects of P7 on bFGF-induced proliferation. Similar results were also observed in gastric cancer and melanoma cells.

It has been reported that PA2G4 inhibits the proliferation and induces the differentiation of human breast cancer cells, and the interaction of PA2G4 with Rb, the product of the reti- 
noblastoma gene, involved in modulating cell cycle progression and cellular differentiation, may be an important mechanism of PA2G4-induced changes in cell proliferation and differentiation (9). In our previous study, PA2G4 was identified as a P7-targeting-bFGF specific protein in colon cancer cells using a proteomic approach (6). In this study, western blot analysis also proved that P7 increased PA2G4 expression in breast cancer cells as observed in colon cancer cells. The increased expression of PA2G4 may partly count for the inhibitory effect of P7 on the proliferation of not only breast cancer cells, but also other cancer cells.

In conclusion, we show that the previously isolated bFGFbinding peptide, $\mathrm{P} 7$, inhibits bFGF-stimulated proliferation in breast cancer cells possibly by causing cell cycle arrest at the $G_{0} / G_{1}$ phase, blocking the activation of the Erk and P38 cascades, and upregulating the expression of growth inhibitor, PA2G4.

\section{Acknowledgements}

This study was supported by grants from the National Natural Science Foundation of China (30973671, 81071800), the Natural Science Foundation of the Zhejiang Province of China (Y2090292), the Natural Science Foundation of the Guangdong Province of China (9151064001000031), the Science and Technology Planning Project of Wenzhou (Y20090244), the Fundamental Research Funds for the Central Universities (X.W.), the Guangdong Provincial 'Thousand-Hundred-Ten Talent Project' (X.W.), and the Guangdong Provincial Key Discipline in Biochemistry and Molecular Biology.

\section{References}

1. Rusnati M and Presta M: Fibroblast growth factors/fibroblast growth factor receptors as targets for the development of antiangiogenesis strategies. Curr Pharm Des 13: 2025-2044, 2007.

2. Gross JL, Herblin WF, Dusak BA, et al: Effects of modulation of basic fibroblast growth factor on tumor growth in vivo. J Nat Cancer Inst 85: 121-131, 1993.

3. Nguyen M, Watanabe H, Budson AE, Richie JP, Hayes DF and Folkman J: Elevated levels of an angiogenic peptide, basic fibroblast growth factor, in the urine of patients with a wide spectrum of cancers. J Nat Cancer Inst 86: 356-361, 1994.

4. Sartippour MR, Zhang LP, Lu M, Wang HJ and Brooks MN: Nipple fluid basic fibroblast growth factor in patients with breast cancer. Cancer Epidemiol Biomark Prev 14: 2995-2998, 2005.

5. Wu X, Yan Q, Huang Y, et al: Isolation of a novel basic FGF-binding peptide with potent antiangiogenetic activity. J Cell Mol Med 14: 351-356, 2010.

6. Wang C, Lin S, Nie Y, et al: Mechanism of antitumor effect of a novel bFGF binding peptide on human colon cancer cells. Cancer Sci 101: 1212-1218, 2010.

7. Wu X, Jia X, Ji Y, et al: Effects of a synthetic bFGF antagonist peptide on the proteome of 3T3 cells stimulated with bFGF. Int J Peptide Res Ther 17: 53-59, 2011

8. Neary JT, Kang Y and Shi YF: Cell cycle regulation of astrocytes by extracellular nucleotides and fibroblast growth factor- 2 . Purinergic Signal 1: 329-336, 2005.

9. Xia XM, Cheng AW, Lessor T, Zhang YX and Hamburger AW: Ebp1, an ErbB-3 binding protein, interacts with $\mathrm{Rb}$ and affects $\mathrm{Rb}$ transcriptional regulation. J Cell Physiol 187: 209-217, 2001. 